\title{
Isolation and Cytotoxicity Test of Dichloromethane Extract of Syzygium malaccense
}

\author{
Novirlin Yosephin Daely, Tukiran* \\ Chemistry Departement \\ Universitas Negeri Surabaya \\ Surabaya, Indonesia \\ tukiran@unesa.ac.id
}

\begin{abstract}
Syzygium malaccense or also known as Malay Apple is one of Myrtaceous plants. It is originally found in India and Malaysia. This plant has strong potential which can be traditional medicine. In the present study, it has been done an isolation the chemical components from dichloromethane extract of the plant and followed by identification of molecular structure on the isolated compound. Based on FT-IR analysis and by comparison with literature data, the isolated compound can be suggested as methyl ester. Cytotoxicity in BHK-21 cells using MTT-assay showed that the isolated compound is non toxic which has \%living cell more than $60 \%$.
\end{abstract}

Keywords-S. malaccense, ester, MTT-assay, BHK-21

\section{INTRODUCTION}

Tropical plants can live well in harsh conditions due to climatic factors, herbivorous, insect or disease pests. Therefore, tropical plants are able to engineer many chemical compounds with various bioactives such as insecticides, antibacterials and cytotoxics. Natural chemical compounds in plants are secondary metabolies such as alkaloids, terpenoids, lignans, phenolic, flavonoids, and polyketides depending on the type of plants [1].

The genus Syzygium is considered one of the largest genera belonging to family Myrtaceae with about 156 species such as S. aqueum, S. aromaticum, S. cumini, S. polycephallum, S. malaccense, S. polyanthum, S. jambos, and S. pycnanthum [2].

S. malaccense falls under the family of Myrtaceae and known as "Malay apple". Some parts of the plant have been applied in traditional medicine. The plant extract of $S$. malaccense has potential to be developed as antimicrobial preservative agent against S. aureus and C. albicans [3]. Its bark extract has been shown to effectively serve a hypoglycemic agent that improved the fasting blood-sugar level and the liver-glycogen depletion [4]. According to its potential, S. malaccense can be the material of medicine or dental product.

The requirements of medicine or dental product are non irritant, biocompatible, non toxic and should not have negative effect against local, systemic or biological environment [5]. Cytotoxicity test use MTT-assay method. MTT is yellow tetrazolium bromide [3-(4,5-Dimethylthiazol2-yl) 2,5-diphenyltetrazolium bromide].

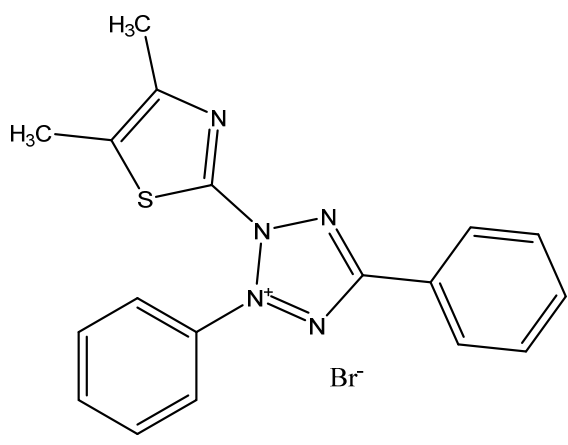

Fig. 1. MTT structure

MTT measure the living of cell based on mitochondria activity whice reduse yellow tetrazolium bromide into insoluble formazan purple sediment. The darker color of purple of solution it means higher the number of living cell.

The present study is designed to isolate the bark extract of $S$. malaccense and evaluate cytotoxicity potentially. Identify of $S$. malaccense dicloromethane extract using different chromatographic techniques. Cytotoxicity test will be carried out by MTT method on BHK-21.

\section{MATERIAL AND METHOD}

\section{A. Extraction}

The bark of Syzygium malaccense was collected from Gondang Manis, Jombang, East Java, Indonesia. The sample was washed with ta water, dried overnight. It was dried and ground. Dried bark was macerated with methanol then partitioned with hexane and dichloromethane. Dichloromethane was evaporated to dryness in a vacuum rotary evaporator.

\section{B. Isolation}

The dichloromethane extract of bark of Syzygium malaccense was isolated with some chromatograhy method use eluent hexane : ethyl acetate $(5: 1)$. Then it was identified with FT-IR Spectrophotometry.

\section{Cytotoxicity Test}

Baby Hamster Kidney (BHK-21) cells were cultivated in a roux bottle and harvested with trypsine versene solution. BHK-21 was put into each 96 well microplate that has added D-MEM media which contain $10 \%$ fetal bovine serum albumin and incubated in $37^{\circ} \mathrm{C}$ for 24 hours. Isolated compound added into 96 well with concentration $12.5 \%$, $25 \%, 50 \%$ and $100 \%$. Microplate well was incubated for 24 
hours. After 24 hours, each well that will be read were added with solution containing MTT reagent in PBS, and then reincubated for 4 hours. Then, each well was added with DMSO and shaked with plate shaker. The wells were read at Elisa reader in 620 wave length. Percentages of the living cells were calculated with the following formula, according to experimental study [6].

\% Percentage of the butng $=\frac{\text { Treatment }+ \text { media }}{\text { cell }+n \pi \text { dita }} \times 100 \%$

\section{RESULT AND DISCUSSION}

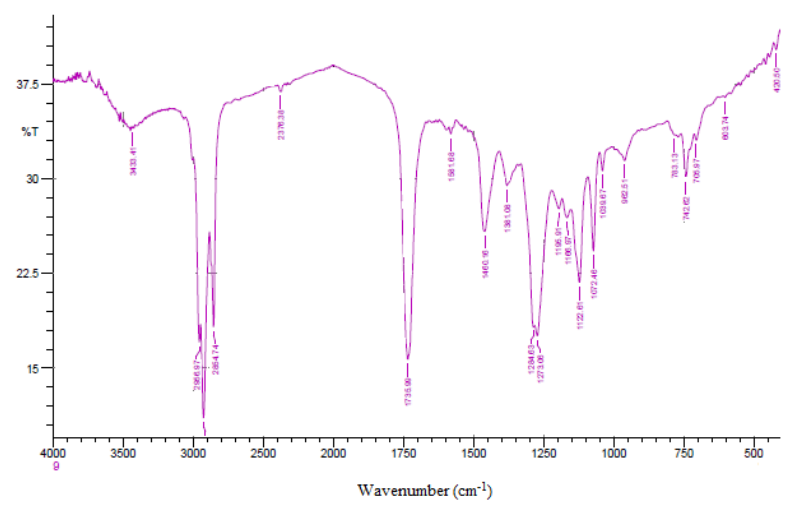

Fig. 2. FT-IR spectrum of isolated compound of S.malaccense

Isolated of dichloromethane extract of bark of Syzygium malaccense is yellow liquid. Identification with FT-IR Spectrophotometry could be seen on Table I.

Figure 1 shown FT-IR spectrum has peak at 1273 and 1284 which are strong C-O possibility as alcohol, ether, carboxylic acid or ester. Peak at 1700 is strong $\mathrm{C}=\mathrm{O}$ possibility as aldehyde, ketone, carboxylic acid or ester

TABLE I. FT-IR OF ISOLATED OF SYZYGIUM MALACCENSE

\begin{tabular}{|c|c|c|c|}
\hline \multicolumn{3}{|c|}{ Wavenumber $\left(\mathrm{cm}^{-1}\right)$} & \multirow[b]{2}{*}{ Type of Bond } \\
\hline $\begin{array}{c}\text { Isolated } \\
\text { compound }\end{array}$ & Methyl Ester [7] & Oleic acid[8] & \\
\hline 3433.41 & 3471.87 & - & $\mathrm{O}-\mathrm{H}, \mathrm{N}-\mathrm{H}$ \\
\hline $2956-2854$ & $2924-2852$ & $2924-2854$ & C-H (alkanes) \\
\hline 2376.38 & $2400-2300$ & - & $\mathrm{C}=\mathrm{C}$ \\
\hline 1753.99 & 1747.51 & 1701 & $\begin{array}{c}\mathrm{C}=\mathrm{O} \text { (Ester) } \\
\text { strong }\end{array}$ \\
\hline 1581.68 & 1625.99 & - & $\mathrm{C}=\mathrm{C}$ \\
\hline 1460.16 & $1462-1375$ & - & $\mathrm{C}-\mathrm{H}$ \\
\hline $1284-1273$ & 1228.66 & 1282 & C-O strong \\
\hline 1122.61 & 1111 & & $\mathrm{C}-\mathrm{O}$ \\
\hline 962.51 & 964.41 & & $\mathrm{HC}=\mathrm{CH}($ trans $)$ \\
\hline $742-705$ & 723.31 & & $\mathrm{HC}=\mathrm{CH}$ (cis) \\
\hline
\end{tabular}

Based on the form of the isolated compound in the form of liquid and the result of FTIR according to Tabel II, isolated compound are thought to be esters. This compound is identified in the wavenumber region $1753 \mathrm{~cm}^{-1}$ which is the absorption of $\mathrm{C}=\mathrm{O}$ carbonyl esters and supported in the region of infrared spectrum $1284-1273 \mathrm{~cm}^{-1}$ which is the absorption of $\mathrm{O}=\mathrm{C}-\mathrm{O}$. This assumption is reinforced by the metyl ester spectrum that has region $1747 \mathrm{~cm}^{-1}$ and $1228 \mathrm{~cm}^{-1}$ also oleic acid at $1701 \mathrm{~cm}^{-1}$ and $1282 \mathrm{~cm}^{-1}$. It's typical of esters. There are two strong peak from 2956-2854 $\mathrm{cm}^{-1}$ shown asymmetric $\mathrm{CH}_{2}$ dan symmetrical $\mathrm{CH}_{2}$. The peak at $1460 \mathrm{~cm}^{-1}$ corresond to asymmetric stretching of $-\mathrm{CH}_{3}$.
Saturated fatty acid is identified at $2956 \mathrm{~cm}^{-1}$ and $2854 \mathrm{~cm}^{-1}$. Whereas unsaturated fatty acids at $1581 \mathrm{~cm}^{-1}$, and supported at the region 742-705 $\mathrm{cm}^{-1}$ which is the absoption of $\mathrm{HC}=\mathrm{CH}$ cis and also $\mathrm{HC}=\mathrm{CH}$ trans at $962.51 \mathrm{~cm}^{-1}$. The stretching of free $\mathrm{OH}$, represented by the absorbance at $3433.41 \mathrm{~cm}^{-1}$. According to the result, indicate strongly that isolated compound of dichloromethane extract of bark of Syzygium malaccense is a methyl ester.

Study of cytotoxicity using MTT assay (in vitro) are used due to well maintained cell integrity and cell is capable of multiplying in toxicity test for medicine or dental material. The result of this study can be applied as accurate basic test [9]. MTT reagen is a yellow tetrazolium salt which can be evaluated cellular enzymatic activity. Mitochondria of living cell can produce dehydrogenase and formed formazan. Formazan that solute in DMSO were read by Elisa Reader is Optical Density [10].

TABLE II. MEAN OF OPTIC FORMAZAN DENSITY AND \%LIVING CELL

\begin{tabular}{|c|c|c|c|}
\hline $\begin{array}{c}\text { Concentration } \\
\text { of isolated }\end{array}$ & $\begin{array}{c}\text { Number of } \\
\text { Sample }\end{array}$ & $\begin{array}{c}\text { Mean of optic } \\
\text { formazan } \\
\text { density }\end{array}$ & \% Living cell \\
\hline $12.5 \%$ & 8 & 0.274 & $80.36 \%$ \\
\hline $25 \%$ & 8 & 0.248 & $74.23 \%$ \\
\hline $50 \%$ & 8 & 0.236 & $71.29 \%$ \\
\hline $100 \%$ & 8 & 0.227 & $69.12 \%$ \\
\hline Control cell & 8 & 0.355 & $100 \%$ \\
\hline Control media & 8 & 0.06 & $0 \%$ \\
\hline
\end{tabular}

In Table 1 shown the group test has significant decrease. Percentage of living cell which is the optic density of dehydrogenase mytochondria enzyme in cells culture of BHK-21 has shown in Table II.

If dehydrogenase is not active due to cytotoxicity effect, formazan will not be formed. The number of formed formazan is equal to enzymatic activity of ling cell. Cell culture BHK-21 is used because it comes from fibroblast cell which are important cell in the pulp, ligament, periodontal, and gingival components [11]

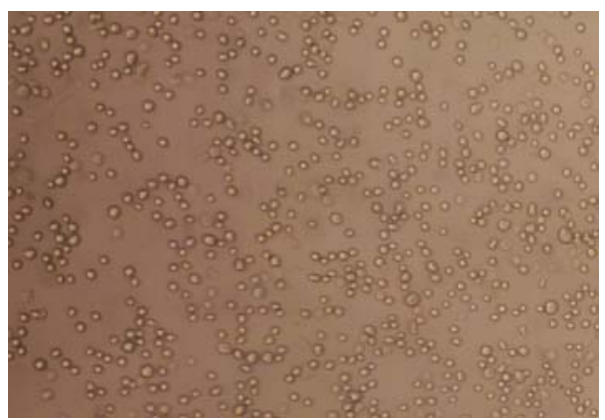

Fig. 3. Baby Hamster Kidney cells

The result show that group $12.5 \%=80.36 \%$, goup $25 \%=74.23 \%$ group $50 \%=71.29 \%$, and group $100 \%=69.12 \%$. Cytotoxicity test of isolated shown $\%$ living of cells are $>60 \%$. It means that isolated is non toxic to BHK-21 cells and safe due to good biocompatibility for medicine and dental material. 


\section{ACKNOWLEDGMENT}

This study is support by Pusat Veteriner Farma Surabaya (Pusvetma).

\section{REFERENCES}

[1] Harborne, J.B. Metode Fitokimia, Penuntun Cara Modern Menganalisis Tumbuhan (diterjemahkan oleh K. Panduwinata dan Soediro, I.), terbitan ke-2, Penerbit ITB, Bandung, 1987.

[2] Mudiana, D. Keragaman Studi Habitat Klampok (Syzygium) di Kabupaten Malang, Jawa Timur. Riset Dasar. LIPI, Purwodadi, 2010.

[3] Y. Norulaiman, K. Ong, S. Saidatul, J. Saiful, A. Nor, and M. Mohd, "Potential og Syzygium malaccense as Antimicrobial Presertative Agent for Tropical Products", The Open Conference Proccedings Journal, 2013, vol 4, pp. 193. [Procceding of the ICNP 2013].

[4] Bairy, K. L., Sharma, A., \& Shalini, A. Evaluation of the hypoglycemic, hypolipidemic and hepatic glycogen raising effects of Syzygium malaccense upon Streptozotocin induced diabetic rats. Journal of Natural Remedies, 2005, 5, 46-51.

[5] Noort VR. Introduction to dental material. $2^{\text {nd }}$ ed. New York: alan R Liss Inc; 1987 p. $227-45$
[6] Meizarini A, Munadziroh E, Rachmadi P. (Cytotoxicity restoration material cyanoacrylate with variation in comparison of powder and liquid use MTT assay method) Sitotoksisitas bahan restorasi cyanoacrylate dengan variasi perbandingan powder dan liquid menggunakan MTT assay. Jurnal Penelitian Medika Eksakta 2005; 6(1): 16-25.

[7] Seniwati D.,Firdaus, and Hendra. (DAG Production of Virgin Coconut oil (VCO) Through the Trans-Esterification Reaction Using The Enxyme Lipase From Rice Bran (Oryza sativa L) Specifict C1820 Immobiled Of The Activated Carbon As Catalyst) Produksi DAG dari Virgin Coconut Oil (VCO) Melalui Reaksi Trans-Esterifikasi Menggunakan Enzim Lipase Dedak Padi (Oryza sativa L.) Spesifik C18-20 Terimobilisasi Karbon Aktif sebagai Biokatalis. Ind. J. Chem Res 2017, 5(1), 444-448

[8] S. Dewi, H. Agus and S. Tursiloadi. (Synthesis of nanoparticles of iron oxide using capping agent) Sintesa Nanopartikel Besi Oksida Dengan Menggunakan Asam Oleat sebagai Capping Reagent. Prosiding Seminar Nasional Kimia dan Pendidikan Kimia .2009.

[9] Siregar F, Hadijono BS. Uji Sitotoksisitas dengan esei MTT. JKGUI 2000; 7:28-32.

[10] Nanci A. Oral histology and cell biology. $2^{\text {nd }}$ ed. Philadelphia: Mosby; 2007. P. 13.

[11] Freshney RI. Culture of animal cells, a manual of basic technique, $2^{\text {nd }}$ ed. New York: Alan R. Lises Inc. 1987: 9, 71, 128, 239 